\title{
Linkage Sharia Banking and Sharia Fintech to Support Halal Industry in Indonesia
}

\author{
Trimulato $^{1 *}$ Ahmad Rodoni $^{2}$, Euis Amalia ${ }^{2}$ \\ ${ }^{1}$ Student Doctoral Program Sharia Banking, Universitas Islam Negeri Syarif Hidayatullah, Indonesia \\ ${ }^{2}$ Universitas Islam Negeri Syarif Hidayatullah, Indonesia
}

\begin{abstract}
The purpose of this study is to describe the development financing of sharia banking, the development of sharia fintech, the development of the halal industry, and the concepts offered in the form of linkage between sharia banking and sharia fintech to support the halal industry in Indonesia. Research uses qualitative method library research. Data sources used are secondary, including Financial Services Authority, Bank Indonesia, LPPOM MUI, and other sources. Data collection technique used library relevant sources theme. Analytical technique used descriptive qualitative, describes development financing sharia banking, sharia fintech, halal industry, and forms linked them for halal industry. Results show growt financing sharia banking December 2020 to August 2021 BUS working capital SMEs grew 4.81 percent. UUS investment SMEs grew 0.86, and investment BPRS grew 5.96 percent. Sharia fintech assets fell -0.42 percent, and players fell 10 percent. Certified halal products 2021 grew 2,531.49 percent. Spending on halal industry food sector is 77.23 total other. Linked between sharia banking and sharia fintech support halal industry, funding business development is provided. Payment instruments can synergize requiring use sharia bank account. Sharia banking and sharia fintech synergize in assisting and marketing products for industry get financing.
\end{abstract}

\section{Introduction}

The main focus of trading activities is to seek profit. In the Islamic concept, seeking profit is not only limited to material gains, but also non-material benefits that are beneficial for the benefit of the life of the world and the hereafter. In the global arena, the halal lifestyle and halal ecosystem are growing rapidly. Every country, both countries with a majority of Muslims and non-Muslims participate actively take part in this industry. Indonesia benefits greatly from a population point of view where the majority are Muslims and it is estimated that this will continue to grow in the future. This population increase increases the demand for halal goods and services. The halal ecosystem has been very easy to form in the territory of Indonesia. A Muslim consumer requires that everything they consume must be halal according to Islamic law. In terms of food, it is very easy and many food products already have a halal label. Consumption of the use of goods and services with halal certainty will continue to increase so that opportunities in the global market are still very large.

\footnotetext{
* Corresponding author: tri.mulato@uin-alauddin.ac.id
} 


\section{$A I C \overline{I E B}$ Annual International Conference \\ on Islamic Economics and Business, 2021}

Currently, the demand for halal products globally continues to increase. For the Southeast Asian market, exports of halal products reached 100 million dollars in 2007. This number has increased by 100 percent compared to the previous year which was only 50 million dollars. Meanwhile, in the European Union, although the Muslim population is a minority and the number is small, the growth is largely due to high purchasing power, such as in France and the Netherlands. For example, Muslims in France spend 30 percent of their income on halal food. The quantity of meat consumption is around 400 thousand metric tons a year. Meanwhile, in the Netherlands, halal food is consumed not only by Muslims but also by non-Muslims, so that the total market demand can reach US $\$ 2.8$ billion per year. The Philippines has also responded to the increasing demand for halal-certified products by encouraging companies to certify their products. Now there are around 50 companies that have obtained halal certification issued by the Filipina Islamic Da'wah Council (IDCP). Several major world producers are also interested in investing in halal products in Malaysia, including Nestle. The growth rate of sales growth of halal/sharia products and services is quite high in each sector, which is supported by the growth of consumers from the Muslim population and non-Muslim consumers who believe in the quality of halal/sharia products and services (Sofyan, 2011).

Indonesia has good potential to develop the halal industry. These potentials include the abundant Muslim population that is projected to reach 256 million people by 2050, the growth of various halal industrial sectors, especially the finance, tourism, and fashion sectors, the recognition of Indonesia's achievements in the eyes of the world, Indonesia's geographical conditions and demographic bonuses, technological developments. as well as the ratification of the Halal Product Guarantee Act number 33 of 2014. This potential can encourage economic growth by increasing the value of exports and foreign exchange reserves. But on the other hand, Indonesia also has challenges in developing this halal industry. The challenges facing Indonesia come from external and internal sources. From an external point of view, the challenges faced by Indonesia are the number of competing countries, the absence of an internationally valid halal certificate. Meanwhile, from an internal point of view, the challenges faced by Indonesia are the lack of halal awareness among the Indonesian people, problems in the implementation of the Halal Product Guarantee Act, and the low awareness of the Indonesian people to competition (Fathoni, 2020).

The role of sharia banking in developing the halal industry in Indonesia must receive full support, both morally and materially, from the central government and local governments as well as interested stakeholders. Opportunities and challenges in developing the halal industry will be even greater. These opportunities and challenges will affect the development and growth of the halal industry. Therefore, an institutional synergy between Islamic banks and the government as well as related ministries and institutions is needed. What Islamic banks can do in optimizing their role in developing the halal industry in Indonesia is through institutional synergy. An institutional synergy that can be carried out by Islamic banks is first, institutional synergy with the government. The forms of institutional synergy carried out by Islamic banks with the government are identification and mapping of areas for the halal tourism sector; support for strengthening regulations, standardization, and supervision processes for halal products. Second, the institutional synergy of Islamic banks with halal industry players. The form of institutional synergy with Islamic banks and the halal industry can be done by identifying and developing industrial models; support for strengthening and providing outlets and market access; provision of financing funds; education and assistance (Husain, 2021).

The developments technological also have great potential for business expansion and network expansion for Islamic finance. Financial technology (Fintech) can bridge SMEs and people who previously did not have access to finance so that they can be more easily integrated with financial products and systems. In addition, the amount of investment in 


\section{$A I C \overline{I E B}$ Annual International Conference \\ on Islamic Economics and Business, 2021}

financial assets can also be increased through Fintech. In recent years, the development of Fintech in Indonesia has experienced positive growth. The latest report notes that Fintech products have the potential to attract 150 million customers in the Islamic banking sector by 2021. As a country with the largest Muslim market in the world where 85 percent of the population is Muslim, and the largest population of internet users with more than 140 million in 2017, Indonesia is very promising. for the development of the Fintech market. Through the participation of Islamic finance in the halal industry and integration with Fintech, it is expected to increase the growth of Islamic finance while providing a broad impact on the distribution of public welfare (Silalahi, 2018).

Strategic efforts are needed in developing halal SMEs which have been eroded by the covid-19 outbreak. If sharia banking is one of the institutions that can contribute to developing SMEs. It's just that in the current conditions sharia bankings are also being eroded due to the Covid-19 outbreak. Moreover, sharia banking has not optimized the distribution of financing for productive activities for SMEs. Other institutions are needed that can help and contribute to developing SMEs during the Covid-19 outbreak. One of the institutions that can contribute to the development of SMEs is sharia fintech. Fintech institutions carry out many of their activities by conducting transactions indirectly to meet or online. Fintech can obtain public funds and channel financing to the business sector without meeting in person, but by utilizing technological advances. This is in line with current conditions, in the midst of the Covid-19 outbreak, with the ease of social distancing, it is right for fintech to still be able to carry out activities without meeting in person. Currently, sharia fintech companies have emerged, with various product variations such as peer-to-peer landing (Trimulato, 2020).

The halal industry will continue to experience growth both nationally and globally. The halal industry is a necessity for many countries to improve their economy. Thus the development of the real sector of the halal industry requires support to be able to grow through financial access from Islamic financial institutions. It's just that currently Islamic bank financing is still dominated by non-productive consumptive financing, while for fintech the level of knowledge, literacy, and public access is still very limited. Sharia banking and sharia fintech can work together to improve the halal industry as the main function of the sharia financial sector, namely sharia finance which will encourage the development of the real sector.

From this description, the author is interested in conducting a more in-depth study related to the form of linkage between sharia banks and sharia fintech in supporting the development of the halal industry. The purpose of this paper is to find out the development of sharia banking, then to find out the development of sharia fintech, as well as the development of the halal industry in Indonesia. It also aims to analyze and describe the form of linkage between sharia banks and sharia fintech in supporting the development of the halal industry. Needs to be a concept of a form of linkage between sharia banking and sharia fintech to support the halal industry that can be applied, with several pre-existing sources, as a differentiator.

\section{Literature Review}

\subsection{Sharia Banking}

Sharia Banking is a Bank that runs its business activities based on Sharia Principles and by type consists of Sharia Commercial Banks and Sharia People's Financing Banks. Sharia Banking is everything related to Sharia Banks and Sharia Business Units, including institutions, business activities, as well as methods and processes in carrying out their business activities. Sharia principles are principles of Islamic law in banking activities based 


\section{$A T \overline{C E B}$ Annual International Conference \\ on Islamic Economics and Business, 2021}

on fatwas issued by institutions that have the authority to determine fatwas in the field of sharia. The principles of Islamic Banking are part of Islamic teachings related to the economy. One of the principles in Islamic economics is the prohibition of usury in various forms and using a system, including the principle of profit-sharing (UU. Nomor 21 Tahun 2008).

Sharia banking as an intermediary institution was not known at the time of the Prophet or his companions. However, investment cooperation activities in trade (buying and selling) and other transactions have been carried out individually by market participants who must follow Islamic sharia rules. Theoretically, the purpose of sharia banking is to facilitate the flow of investment from parties who have excess (surplus spending units) channeled to parties who need funds (spending unit deficit) and ultimately facilitate the circulation of economic resources. Thus, it will smoothen the flow of the economy, expedite the activities of the real sector, to be able to grow the economy. Sharia banking industry services to customers are equipped with various financial instruments that are expected to meet the needs of financial transactions that comply with sharia principles. In addition to being economically profitable, it can also not violate sharia principles, so it's not just material. The Islamic financial instruments offered must of course be able to cover various levels of society and industry, including transaction needs for the consumption sector. Likewise with productive products. In general, Islamic financial products can be divided into two main groups, namely; basic Islamic financial products used in traditional banking activities and development products. Products that need to be designed can meet the needs of the community but are also in line with sharia principles. The basic products of Islamic finance are used by Islamic banking institutions in carrying out their basic activities as intermediary institutions whose function is to transform the community's liquid assets into various long-term investments. However, in line with the development of activities that occur, Islamic banking products need to develop a variety of financial products to be able to flexibly facilitate transactions in different currencies and hedging instruments. As well as many more Islamic banking products that will meet the needs of the community, innovation is very much needed (Darsono.et al, 2017).

\subsection{Sharia Fintech}

Fintech is short for financial technology (financial technology). Fintech is a popular term in recent years. When someone hears the term fintech, what comes to mind is all the convenience and speed of financial transactions, such as the ease and speed of payments, borrowing, sending, and so on. With fintech, it is hoped that it can save time, thoughts, energy, and costs. In essence, fintech is a technology-based financial service. Payment of electricity bills, vehicle installments, or insurance premiums online are some examples of fintech products that are often used in daily life, as well as sending money or checking balances through online banking (Fahlefi, 2018).

Sharia finance is a financial system whose implementation is based on Islamic law (sharia). The establishment of this system is based on the prohibition in Islam to lend or collect loans by charging interest on loans (riba), as well as the prohibition to invest in businesses categorized as forbidden (haram), which cannot be guaranteed by the conventional system. A fintech is a software and modern technology-based business that provides financial services. Fintech companies are generally start-up companies that provide financial services and solutions to customers such as mobile payments, money transfers, loans, fundraising, and even asset management. Fintech Syariah means financial services and solutions provided by technology companies/fintech startups, which are based on Islamic/sharia laws (Fintech, 2017). 


\section{$A I C \overline{I E B}$ Annual International Conference \\ on Islamic Economics and Business, 2021}

Principles is the provision of financial services based on sharia principles that bring together or connect financiers with financiers to perform financing contracts through an electronic system using the internet network. An electronic System is a series of electronic devices and procedures that function to prepare, collect, process, analyze, store, display, announce, transmit, and/or disseminate electronic information in the field of financial services. Information Technology is a technique for collecting, preparing, storing, processing, announcing, analyzing, and/or disseminating information in the field of financial services. A financier is a party who has funds and intends to provide financing to assist parties who need funds. Financing Recipients are parties who use funds sourced from the Financing Providers (DSN-MUI, 2018).

\subsection{Halal Industry}

Halal Industry often associated with an attempt to produce a product (goods and services) that are following the provisions of the Islamic religion (sharia). This definition began to emerge recently due to the high demand for halal products and services in the world. Previously, it was known that the halal industry was associated with the halal economy, where the mention of the halal economy was much earlier known than the halal industry. Thomson Reuters in collaboration with Dinar Standard contained in the 2019 edition of the State of the Global Islamic Economy Report stated that the halal economy consists of sectors whose main products and services are structurally influenced by Islamic law, driven by values, consumer lifestyles. and business practices. The definition of the halal industry in language consists of two words, namely industry and halal. According to the Big Indonesian Dictionary (KBBI), it is stated that industry is the activity of processing or processing goods using facilities and equipment, such as machines. Meanwhile, halal means permitted (not prohibited by sharia), so the halal industry is defined as the activity of processing or processing goods using facilities and equipment permitted by Islamic sharia. In its implementation, the halal industry, among others, has been regulated in Law no. 33 of 2014 concerning the Guarantee of Halal Products (Sukoso, et al. 2020).

Halal Products are products that have been declared halal following Islamic law. Halal Product Processing, hereinafter abbreviated as $\mathrm{PPH}$, is a series of activities to ensure the Halalness of Products including the supply of materials, processing, storage, packaging, distribution, sales, and presentation of Products. Halal Product Guarantee, hereinafter abbreviated as JPH, is legal certainty regarding the halalness of a Product as evidenced by a Halal Certificate. The halal label is a sign of the halalness of a product. Halal Certificate is an acknowledgment of the halalness of a Product issued by BPJPH based on a written halal fatwa issued by MUI (UU Nomor 33, 2014).

Four main industries can be developed optimally by Indonesia as a country with the largest Muslim population in the world, namely the halal tourism industry, the halal food industry, the halal fashion industry, and the halal finance industry. Mapping and identification of the potential of each type of industry are very important as the first step in developing the halal industry. What is very important to do is to create an ecosystem that can develop the four halal industries at the same time by ensuring the optimization of the performance of halal value chain management so that the quality and standards of the products and services produced are very important in addition to prioritizing halal. In the mapping process, it is known that each halal industry has potential that can be improved so that it has added value while maintaining Indonesian culture. Five strategic steps need to be taken, namely increasing competitiveness, certification, coordination, publication, and cooperation. For this reason, it requires the involvement and coordination of the government, policymakers and cross-sectoral industry players in building the halal industry in Indonesia, as well as the active role of the community as agents of promoting sharia products in the 


\section{$A I C \overline{C E B}$ Annual International Conference \\ on Islamic Economics and Business, 2021}

digital world so that the development of the halal industry can enter the global market immediately (Saputri, 2020).

Opportunities to synergize between Sharia Banks and Sharia Fintech to develop MSMEs in Indonesia are very wide open. This is motivated by the gap or gap in capital support from Islamic banks for SMEs actors. The pattern or model of synergy between Islamic Banks and Sharia Fintech can be carried out through several cooperation schemes, namely cross-selling schemes, channeling schemes, joint financing schemes. together Sharia Banking and Sharia Fintech form a Fintech consortium. The benefit of the synergy between Islamic Banks and Fintech in the context of developing SMEs is that people increasingly have choices in investing or obtaining financing sources that are following Sharia principles; implementation of SMEs empowerment through the provision of training and assistance in the context of increasing SMEs productivity and competitiveness through the participation of Syariah Banks and Syariah Fintech; provide opportunities for the creation of innovative new products for the development of SMEs in Indonesia; stimulate and facilitate practical, convenient and safe financial services as well as improve financial education, especially for areas that have so far been limited to financial services; and encourage financing in the SME segment, so that both Islamic Banks and Syariah Fintech can increase the market share of MSME financing, which as a whole can increase the portion of the financing to SMEs. The challenge of synergy between Islamic Banks and Fintech in increasing the development of SMEs is the need for regulatory support for policy relaxation in developing synergies between Islamic Banks and Sharia Fintech; availability of human resources who have competence in the field of Sharia Fintech (Haris, 2020).

The role of sharia fintech in financial inclusion in MSMEs in Pekalongan, Batang and Pemalang Regencies. It can be seen that many SME owners use applications and collaborate with banks and Savings and Loans Cooperatives to provide easy access to various types of bank savings and loan cooperative financial services, now financial institutions can reach all SMEs to remote areas. Sharia fintech has opened access to business financing that is easier and faster than banking institutions and savings and loan cooperatives. The role of Islamic fintech in financial inclusion in SMEs is that Islamic fintech has contributed a lot to the empowerment of SMEs and the local economy. This is done so that the credibility or public trust in the sustainability of the Sharia Fintech business can be increased and it is recommended for Regulators to be able to make rules or policies that are specifically aimed at encouraging the realization of synergy between Sharia Banks and Sharia Fintech (Winarto, 2020).

The fintech companies reviewed have promoted the idea of financial inclusion, for example, financing underdeveloped sectors such as agriculture and small and micro enterprises (SMEs). In addition, selected fintech companies were also found to collect and distribute Islamic social funds such as infaq (charity spending), waqf (waqf) and alms (voluntary charity). In addition, the company was also found to start a charity program for the underprivileged. To some extent, these findings are identical to the company's efforts to promote the SDGs to end poverty (SDG 1) and hunger (SDG 2) and reduce inequality (SDG 10) (Hudaefi, 2020).

\section{Method}

The type of research used in this research is qualitative. With a library research approach, with various sources related to the development of Islamic bank financing, the development of Islamic fintech, the development of the halal industry, as well as the form of linkage between sharia banks and sharia fintech in supporting sharia fintech. The variables that are the focus of this research are; development Financing of sharia banking, the development of sharia Fintech, the development of the Halal Industry, as well as the concept of linkage 


\section{$A I C \overline{I E B}$ Annual International Conference \\ on Islamic Economics and Business, 2021}

between sharia banking and sharia fintech to support the halal industry. Based on previous research.

The source of data used in this study is secondary, namely data that has been presented by certain institutions and then processed the data. Sources of data used in this study were from the Financial Services Authority (OJK), and the National Committee for Islamic Economics and Finance (KNEKS) and LPPOM MUI. And from several other sources.

The data collection technique used in this research is literature from several sources that are considered relevant to the research theme. Library research is a research activity carried out by collecting information and data with the help of various materials in the library or sources from the internet related to the problem to be solved. Activities are carried out systematically to collect, process, and conclude data by using certain methods/techniques to find answers to the problems encountered (Sari \& Asmendri, 2020). Then according to Sugiyono (2018) said that literature study is related to theoretical studies through references related to values, culture, and norms that develop in the social situation under study. This literature research is inseparable from the scientific literature. This library research does not go into the field directly to meet with respondents because the data is obtained from library sources in the form of books or documents which are then read, recorded, and analyzed (Sofiah et al., 2020). Namely about sharia banking, sharia fintech, and the halal industry. From several good sources from books, journals, and others.

The analytical technique used in this study is a qualitative descriptive analysis technique. Description in qualitative research is one kind of research. In qualitative research, the type of description does not need a hypothesis because it is not intended to prove something true (Subandi, 2011). This type of qualitative descriptive research (QD) is generally used in social phenomenology. The main strength of qualitative research lies in the flexibility of the researcher's style to describe the flow of research with a very open research problem (Wiwin Yuliani, 2018). Namely analyzing, describing, and describing the conditions of the research object. In this case, it describes the development of sharia banking, the development of sharia fintech, the development of the halal industry, and the form of linkage between sharia banks and sharia fintech in supporting the development of the halal industry.

\section{Result and Discussion}

\subsection{The Growth of Financing Sharia Banking}

Tabel 1. The Growth of Financing Sharia Banking

\begin{tabular}{|c|c|c|c|c|c|}
\hline No & $\begin{array}{c}\text { Type Of } \\
\text { Sharia } \\
\text { Banking }\end{array}$ & Type Of Financing & $\begin{array}{c}\text { December } \\
2020\end{array}$ & $\begin{array}{c}\text { August } \\
\mathbf{2 0 2 0}\end{array}$ & $\begin{array}{c}\text { Growth } \\
(\%)\end{array}$ \\
\hline 1 & $\begin{array}{l}\text { Bank Umum } \\
\text { Syariah (BUS) }\end{array}$ & $\begin{array}{l}\text { Working Capital } \\
\text { a. SMEs } \\
\text { b. Non SMEs } \\
\text { Investment } \\
\text { a. SMEs } \\
\text { b. Non SMEs } \\
\text { Consumption } \\
\text { a. Non SMEs }\end{array}$ & $\begin{array}{l}\text { a. } 35.579 \\
\text { b. } 45.386 \\
\text { a. } 21.739 \\
\text { b. } 34.464 \\
\text { a. } 109.364\end{array}$ & $\begin{array}{l}\text { a. } 37.291 \\
\text { b. } 41.928 \\
\text { a. } 23.602 \\
\text { b. } 33.424 \\
\text { a. } 116.351\end{array}$ & $\begin{array}{l}\text { a. } 4,81 \\
\text { b. }-7,62 \\
\text { c. } 8,57 \\
\text { d. }-3,02 \\
\text { a. } 6,39\end{array}$ \\
\hline
\end{tabular}




\section{$A T \overline{I E B}$ Annual International Conference \\ on Islamic Economics and Business, 2021}

\begin{tabular}{|c|c|c|c|c|c|}
\hline 2 & $\begin{array}{lr}\text { Unit Usaha } \\
\text { Syariah (UUS) }\end{array}$ & $\begin{array}{l}\text { Working Capital } \\
\text { a. SMEs } \\
\text { b. Non SMEs } \\
\text { Investment } \\
\text { a. SMEs } \\
\text { b. Non SMEs } \\
\text { Consumption } \\
\text { a. Non SMEs }\end{array}$ & $\begin{array}{ll}\text { a. } & 7.300 \\
\text { b. } & 26.643 \\
\text { a. } & 4.917 \\
\text { b. } & 26.066 \\
\text { a. } & 72.486\end{array}$ & $\begin{array}{l}\text { a. } 6.539 \\
\text { b. } 27.505 \\
\text { a. } 4.959 \\
\text { b. } 24.232 \\
\text { a. } 80.979\end{array}$ & $\begin{array}{l}\text { a. }-10,42 \\
\text { b. } 3,24 \\
\text { a. } 0,86 \\
\text { b. }-7,04 \\
\text { a. } 11,72\end{array}$ \\
\hline 3 & $\begin{array}{l}\text { Bank } \\
\text { Pembiayaan } \\
\text { Rakyat } \\
\text { Syariah } \\
\text { (BPRS) }\end{array}$ & $\begin{array}{ll}\text { a. Working Capital } \\
\text { b. Investmen } \\
\text { c. Consumption }\end{array}$ & $\begin{array}{lr}\text { a. } & 4.842 .629 \\
\text { b. } & 1.437 .931 \\
\text { c. } & 4.400 .939\end{array}$ & $\begin{array}{l}\text { a. } 4.943 .829 \\
\text { b. } 1.523 .657 \\
\text { c. } 4.783 .157\end{array}$ & $\begin{array}{l}\text { a. } 2,09 \\
\text { b. } 5,96 \\
\text { c. } 8,69\end{array}$ \\
\hline 4 & Total & & 394.625 & 408.061 & 3,41 \\
\hline
\end{tabular}

Source; Financial Services Authority. (OJK) Sharia Banking Statistics August 2021 (processed)

The data above shows the development of financing product distribution in 3 types of Islamic banks, namely Sharia Commercial Banks (BUS), Sharia Business Units (UUS), and Sharia People's Financing Banks (BPRS). Distribution of financing for three purposes, namely working capital, investment, and consumption. The data above is the development of Islamic bank financing in the period December 2020 to August 2021. Financing at Islamic banks is still dominated for consumptive purposes at BUS and UUS, while at BPRS is dominated by working capital financing. Overall Islamic bank financing grew by 3.41 percent. Working capital financing for non-SME BUS decreased by -7.6 percent, and nonSMEs working capital investment financing decreased by -3.02 percent. Furthermore, financing at UUS experienced the largest decline in working capital for MSMEs, which fell by 10.42 percent, and non-MSME investment fell by -7.04. Financing at BPRS experienced growth for working capital by 2.09 percent, investment by 5.96 percent, and consumption by 8.69. Under these conditions, sharia banking need to be encouraged to channel them for productive activities that support the real sector, especially in the form of working capital. Sharia banking as sharia finance industry are expected to support real sector economic activities, including the halal industry.

If sharia banking has a major role in the halal industry in Indonesia, not only sharia banking will progress, but also the Indonesian economy as a whole will also advance. There are four major sectors that represent great opportunities in developing the halal industry, namely, the food industry, the pharmaceutical industry, the fashion industry and the tourism industry. Sharia banking can have a role in developing these four sectors, including cooperation with companies that will issue products with halal labeling to financially use sharia banking (Handayani, 2017). On the other hand, the increasing Muslim middle class in Indonesia makes the halal industry will continue to grow in the future. The growing middle class is a sign that the consumption ability is also increasing. On the other hand, the development of information technology is one of the triggers for increasing public awareness of halal products in Indonesia. The link between Indonesia's economy which is dominated by consumption, the increasing middle class, and increasing public awareness of the existence of halal products is a big opportunity for Islamic Banking (LPPI, 2019). Halal is a universal indicator to improve the quality of living standards. The halal industry is a necessity so that it can participate in promoting sustainable economic growth. Therefore, the halal industry must be fought for and maintained for its existence (Sungkawaningrum, 2019). The development of the halal industry is growing rapidly. However, in its development, these industries are often constrained by the funds and sources of capital needed by the company. 


\section{$A I C \overline{I E B}$ Annual International Conference \\ on Islamic Economics and Business, 2021}

Several products from the Islamic capital market that can be selected and used by the halal industry in obtaining funding are IPO, Sukuk, and ECF. It is hoped that this research can be useful for the development of the halal industry through the Islamic capital market in the future (Melisa \& Khikmawati, 2021).

\subsection{The Growth of Sharia Fintech}

Tabel 2. The Growth Sharia Fintech Peer To Peer Landing (P2P)

\begin{tabular}{|l|l|c|c|c|}
\hline No & \multicolumn{1}{|c|}{ Indicator } & $\begin{array}{c}\text { December } \\
\mathbf{2 0 2 0}\end{array}$ & $\begin{array}{c}\text { September } \\
\mathbf{2 0 2 1}\end{array}$ & Growth (\%) \\
\hline 1 & Total Asset Fintech & $3.711,16$ & $4.474,86$ & 20,58 \\
\hline 2 & Total Players Fintech & 149 & 107 & $-28,19$ \\
\hline 3 & Asset Sharia Fintech & 74,68 & 74,37 & $-0,42$ \\
\hline 4 & Player Sharia Fintech & 10 & 8 & -20 \\
\hline
\end{tabular}

Source: Financial Services Authority. Fintech Lending Statistics (processed data)

The data above shows the development of peer-to-peer (P2P) fintech in the period from December 2020 to September 2021, the total P2P Fintech assets grew by 20.58 percent. Fintech players experienced a decline of -28.19 percent. The total of 107 fintech players and sharia fintech players were only 8 or decreased by -20 percent. Including sharia fintech assets decreased by -0.42 percent. P2P sharia fintech players experienced a decline because they could not meet the conditions required by the OJK. However, Islamic fintech still has great potential in the development of the real sector. Sharia fintech can support the growth of the real sector, including for business actors in the halal industry. Sharia P2P fintech has twoway opportunities for investors, and access to funding for business actors according to sharia principles. The existence of sharia fintech is not yet familiar to the public so it requires greater socialization, access to fintech technology can be accessed anytime and anywhere. Several Islamic P2P fintech focuses on providing financing for the real sector of SMEs. Plus now there has been a fintech crowdfunding that supports the real sector.

If all institutions are integrated in carrying out their respective roles in the same direction, the Islamic finance ecosystem will form a strong halal industry community. Finally, it is recommended that all parties, including financial institutions, professional institutions, social institutions and government institutions, have the same vision in developing the halal industry. Therefore, it is necessary to develop a verified roadmap in designing strategies to guide these institutions. If the halal industry ecosystem is developed in a measurable and targeted manner, the halal industry can become a source of national competitive advantage (Utomo et al., 2020). Sharia fintech is here as a solution to community problems that cannot be served and fulfilled by Islamic banking. The development of the fintech industry, which prioritizes the elements of speed and convenience in the financial sector, is closely related to the development of technology and internet networks. Likewise, the close relationship that Islamic fintech has with the halal industry, namely a complementary relationship and mutualism between the two. In simple terms, the mechanism for the relationship between sharia fintech and the halal industry can be described in the sentence, "Sharia finance becomes a halal lifestyle amplifier, especially for those who need financial services". As well as being part of the halal industry, the sharia fintech industry also has principles regarding operations that must meet the muamalah contract and business schemes in the Islamic economy (Yudha, et. 2021).

The advantages that are obtained when using sharia fintech services are that between recipients of loans or financing there is no need to meet face to face and financial needs are 


\section{$A I C \overline{C E B}$ Annual International Conference \\ on Islamic Economics and Business, 2021}

more easily fulfilled and like Muslims, namely carrying out financial activities based on Islamic sharia law (Wahyuni, 2019). The Fintech era is an unavoidable necessity, the Islamic economy needs to answer the challenges of FinTech by issuing products or policies that are in line with FinTech developments and do not conflict with sharia principles. expand access to the Islamic banking market. The role and function of Islamic banks are more than just a relationship between debtors and creditors, but there is a partnership relationship between shohibul maal and mudharib which has an impact on the welfare of both parties (Subagiyo, 2019).

\subsection{The Growth Of Halal Industry}

Table 3. The Growth Of Number Certifacate Halal Industry LPPOM 2021

\begin{tabular}{|l|l|l|l|l|}
\hline No & \multicolumn{1}{|c|}{ Components } & \multicolumn{1}{|c|}{2015} & September 2021 & $\begin{array}{c}\text { Growth } \\
(\%)\end{array}$ \\
\hline 1 & Number Of Companies & 1052 & 16.856 & 1502,28 \\
\hline 2 & Number SH (Halal Certifacate) & 1404 & 40.732 & 2801,14 \\
\hline 3 & Number Of Producte & 46260 & 1.217 .328 & 2531,49 \\
\hline
\end{tabular}

Source: LPPOM MUI. Statistics of MUI Halal Certified Products for the Period 2015 to 2021 (data processed)

From the data above, it shows that there is a development in the number of halal certification products issued by LPPOM from 2015 to September 2021, all of which have a very significant increase. The number of companies that gave business labels to their products grew by $1,502.28$ percent, then the number of halal certificates grew by $2,801.14$ percent, and the number of products that had obtained halal certification grew by $2,531.49$. Thus, the development of the goods and service industry will continue to grow, which obtains the MUI halal certificate, to increase public access to halal products.

\subsection{Total World Industry Halal Expenditure}

Table 4. Total Shopping for Halal Products in the World 2018

\begin{tabular}{|l|l|c|c|}
\hline No & Halal Industry Sector & Nilai (USD, Miliar) & Porsi \\
\hline 1 & Halal Foods & 173 & 77,23 \\
\hline 2 & Halal Travel & 11 & 4,91 \\
\hline 3 & Halal Fashion & 21 & 9,38 \\
\hline 4 & Halal Media and Tourism & 10 & 4,47 \\
\hline 5 & Halal Farmacy & 5 & 2,23 \\
\hline 6 & Halal Cosmetics & 4 & 1,78 \\
\hline 7 & Total & 224 & 100 \\
\hline
\end{tabular}

Source: Thomson Reuters in Halal Ekosistem Halal, 2020 Bank Indonesia

The data shows that there is a portion of each halal product spent globally in the world in 2018. The largest sector in shopping for halal products, namely the halal food and beverage sector, takes the largest portion, which is 77.23 percent, then the halal fashion sector at 9.38 percent., and 4.91 percent halal travel. From this condition, various halal sectors still have great opportunities and potential to be developed globally, with various supports from various parties so that the halal industry can develop and compete in the global arena. As the country of Indonesia is the world's largest Muslim, everything requires halal legality so that it can be used and consumed safely, comfortably, and quietly. The potential for halal products to be accepted in the global realm can continue to grow with support from the government and other industries to be able to support it, including in its development which requires no small amount of capital. In this position, the Islamic finance industry is an institution that can 


\section{$A T \overline{C E B}$ Annual International Conference \\ on Islamic Economics and Business, 2021}

support the development of the real sector, including the halal industry sector, and SMEs. This is an opportunity for Islamic banks and Islamic finance to be able to increase their productive portion, not just increase consumption.

Halal certification by MUI plays an important role because it is defined as the inspection of certain production processes and meets the hygienic, sanitary, and safety requirements. Products certified Halal by the board may use the registered trademark halal logo. Currently, halal certification is voluntary but in 2019 it will be mandatory. By having a halal certificate, the product will have many competitive advantages. Today, a halal certificate is a guarantee that a particular product has been thoroughly investigated and declared compliant with Islamic sharia law. Hence convincing Muslims to consume the product (BAPPENAS, 2018).

The halal economy has become a very crucial issue in the context of the development of the global Sharia economy. The halal economy is a holistic and integral concept with Sharia values. The biggest problem is that there is no integrated system between the halal industry and Islamic financial institutions in Indonesia. An alternative strategy related to strategic partnerships between the Islamic finance industry and the halal industry in Indonesia is to strengthen regulations and policies. Building a halal lifestyle strategy and strengthening human resource capacity in the financial sector and the sharia industry in general. aspects of the priority strategy for the criteria for the strategic partnership of Islamic finance and the halal industry where regulatory and policy criteria rank first and foremost (Amalia and Nurhidayah, 2020).

Indonesia is seen as not optimal in pursuing the integrity of halal products along the supply chain. Whereas ideally, the government's role in ensuring the integrity of the halal industry supply chain is needed. So far, the government's role is seen as not yet comprehensive in covering supply chain activities, starting from planning, developing, implementing, regulating, promoting, and educating producers and consumers of the halal industry. In addition, the government's role does not include the establishment of institutions, collaboration between public institutions, and training of professional auditors to ensure the integrity of the reliable halal industry supply chain. This condition reflects that the supply chain concept has not been widely understood as a very important variable for the development of the halal industry. Ideally, the integrity of halal industrial products should be protected by all means and all necessary steps and should be taken by all parties involved in the supply chain. One way for the sharia ecosystem in Indonesia to develop rapidly is to improve the halal ecosystem (halal value chain) through strengthening regulations. contribution to the importance of the concept of institutional strengthening as an integral part of strengthening the supply chain integrity of the halal industry. The supply chain has a dominant role in strengthening regional competitiveness, particularly for poverty alleviation, inequality reduction, and employment. Institutional strengthening is aimed at minimizing the challenges of developing the domestic halal industry, to strengthen regional competitiveness for quality development models. The most in-depth discussion lies in the factors that can improve the integrity of the halal industry supply chain (Nasution, 2020).

\subsection{Strengthening the Halal Industry With Linkage Sharia Banking and Sharia Fintech}

The role of the government regarding the improvement of the halal industrial sector is not only focused on the results of decisions or laws, some steps and strategies can be taken from an early age, namely by linking the industries and business actors so that they can develop this halal industry. This role is inseparable from the role of the Islamic financial services industry, namely Islamic banking. The role of Islamic banking is very important because Islamic banking directly contributes to the Islamic financial market which requires its industry and operations to be halal and sharia-compliant. In addition, Islamic banking also 


\section{$A I C \overline{C E B}$ Annual International Conference \\ on Islamic Economics and Business, 2021}

has a direct relationship with its partners, namely customers where customers are business actors or entrepreneurs who are engaged directly in the real sector with various businesses being run. This is a very good situation and very helpful in the development of the halal industry. The direct contribution that can be played by Islamic banking is by giving instructions to its customers to be able to get halal certification from a halal institution, for example, if there are customers who are in the process of applying for financing to a sharia bank, the customer can register his business with the Indonesian Ulema Council certification agency. MUI). This is of course a policy that can be viewed from two sides, namely the positive side and the negative side. When viewed from the positive side, it can certainly increase the number of businesses registered with halal institutions, if viewed from the negative side it can be burdensome for customers (Rahmayati, 2018).

Sharia banking and fintech have the potential to be exploited by opportunities in the financial industry. With internal banking capital and fintech capital as adequate financial services in terms of strength, namely the existence of other institutional controls such as DPS, human resource control, human resources that uphold management policies, a fairer system, and a strong capital structure for products. development. So that technological advancement opportunities in the industrial era 4.0 can be optimized with the right strategy to support the expected business growth. The collaboration model of sharia banking and fintech is analyzed using ANP. Sharia banking and fintech synergize to improve sharia business (Swastiratu et al., 2019).

The linked form between sharia banking and sharia fintech in supporting the development of the halal industry, by supporting funding from the capital. Sharia banking and sharia fintech can synergize in the form of partnerships in the development of the halal industry. Halal industry business actors can improve quality and quantity by gaining access to financing from sharia banking and sharia fintech. In addition to obtaining additional capital, the industry can obtain business development assistance. The collaboration of sharia banking and sharia fintech can be partnered by using musharaka, to finance the halal industry. All business actors who obtain financing can be assisted in obtaining halal certificates. The collaboration between the two can be carried out with the support of policies and regulations to be able to synergize with each other. Business actors who cannot access sharia banking can be transferred to sharia fintech institutions to obtain business funding. Likewise, if sharia fintech obtains a large business funding application, it can synergize with sharia banking. Sharia fintech has more flexible and easier access to finance when compared to sharia banking. It's just that sharia bankinging has more funds than limited fintech. Fintech can participate in marketing the halal products that it has financed, as well as sharia banking can participate in promoting the halal products it finances, and participate in certain activities. Sharia fintech and sharia banking have the potential to develop and finance the productive sector of the halal industry. Currently, the financial sector and the halal industry are experiencing good growth, so they can strengthen each other. Sharia banking and sharia fintech earn income from the halal industry, as well as the halal industry, which will develop with the help of capital from Islamic financial institutions. In addition to using musharaka partnerships, sharia banking and fintech also use mudharaba contracts and other contracts to support the halal industrial sector. Including the use of fintech payment instruments may require the industry to use sharia banking accounts.

\section{Conclusion}

The development of financing sharia banks in 2021 will experience growth for Islamic Commercial Banks for SMEs working capital to grow by 4.81 percent. Sharia Business Unit (UUS) financing, SMEs investment financing grew by 0.86 , and BPRS financing for investment grew by 5.96. Furthermore, the growth of sharia fintech assets decreased by -0.42 


\section{$A I C \overline{I E B}$ Annual International Conference \\ on Islamic Economics and Business, 2021}

percent, and players experienced a decrease of 10 percent. As a result of the disabled sharia fintech actors. And the development of certified halal products in 2021 will grow by 2531.49 percent. Globally, the largest food sector halal industry spending contributed 77.23 of the total other halal industries.

Linked between sharia banking and sharia fintech in supporting the halal industry, can be done by providing business development funding capital. The linked form that can be carried out by sharia banking and sharia fintech can use musharaka contracts, in funding large industries or using other contracts. Other forms synergize in information and access. As well as the form of collaboration obligations for industry players who are financed are required to carry out halal certification. Then the means of payment can synergize requiring the use of a sharia bank account. Sharia banking and sharia fintech can synergize in terms of assistance and product marketing for industries that receive financing.

\section{References}

Amali, E. N. (2020). Strategies for Strengthening Halal Industries towards Integrated Islamic Economic System in Indonesia: Analytical Network Process Approach. In Al-Iqtishad: Jurnal Ilmu Ekonomi Syariah (Vol. 12, Issue 1). https://doi.org/10.15408/aiq.v12i1.16225

BAPPENAS. (2018). Masterplan Ekonomi Syariah Indonesia 2019-2024. Kementerian Perencanaan Pembangunan Nasional/ Badan Perencanaan Pembangunan Nasional.

Darsono.et al. (2017). Masa Depan Keuangan Syariah di Indonesia. Tazkia Publishing \& Bank Indonesia.

DSN-MUI. (2018). Fatwa Dewan Syariah Nasional-Majelis Ulama Indonesia No: 117/DSNMUI/II/2018 Tentang Layanan Pembiayaan Berbasis Teknologi Informasi Berdasarkan Prinsip Syariah. 14.

Fahlefi, R. (2018). Inklusi Keuangan Syariah Melalui Inovasi Fintech Di Sektor Filantropi. Batusangkar International Conference III, 205-212.

Fathoni, M. A. (2020). Potret Industri Halal Indonesia: Peluang dan Tantangan. Jurnal Ilmiah Ekonomi Islam. https://doi.org/10.29040/jiei.v6i3.1146

Fintech, T. G. B. F. S. (2017). Kajian Bisnis Fintech Syariah. Telkom Digital Services. https://doi.org/10.1111/j.1365-2966.2008.13419.x

Handayani, H. Y. dan D. L. (2017). Strategi Perbankan Syariah Dalam Menyokong Indonesia Menjadi Trend Setter Industri Halal. Baabu Al-Ilmi.

Haris, M. (2020). Synergy Bank Syariah And Financial Technology In Development Of Micro, Small And Medium Businesses In Indonesia. Jurnal Reviu Akuntansi Dan Keuangan. https://doi.org/10.22219/jrak.v10i1.11258

Hudaefi, F. A. (2020). How does Islamic fintech promote the SDGs? Qualitative evidence from Indonesia. Qualitative Research in Financial Markets. https://doi.org/10.1108/QRFM-05-2019-0058

Husain, S. A. (2021). Optimalisasi Peran Bank Syariah dalam Mengembangkan Industri Halal di Indonesia Melalui Sinergi Kelembagaan. JES (Jurnal Ekonomi Syariah). https://doi.org/10.30736/jesa.v6i2.149

Melisa, \& Khikmawati, L. (2021). Optimalisasi Potensi Industri Halal Di Indonesia Melalui Peran Pasar Modal Syariah. Al-Iqtishod: Jurnal Ekonomi Syariah.

Nasution, L. Z. (2020). Penguatan Industri Halal bagi Daya Saing Wilayah : Tantangan dan Agenda Kebijakan. Journal of Regional Economics Indonesia.

Rahmayati, R. (2018). Strategi Perbankan Syariah Sebagai Solusi Pengembangan Halal Industry di Indonesia. AT-TAWASSUTH: Jurnal Ekonomi Islam. https://doi.org/10.30821/ajei.v1i1.2746

Saputri, O. B. (2020). Pemetaan Potensi Indonesia Sebagai Pusat Industri Halal Dunia. Jurnal 


\section{$A I C \overline{I E B}$ Annual International Conference \\ on Islamic Economics and Business, 2021}

Masharif Al-Syariah: Jurnal Ekonomi Dan Perbankan Syariah.

Sari, M., \& Asmendri. (2020). Penelitian Kepustakaan (Library Research) dalam Penelitian Pendidikan IPA. Natural Cience : Jurnal Penelitian Bidang IPA Dan Pendidikan IPA.

Sofiah, R., Suhartono, S., \& Hidayah, R. (2020). Analisis Karakteristik Sains Teknologi Masyarakat (Stm) Sebagai Model Pembelajaran: Sebuah Studi Literatur. Pedagogi: Jurnal Penelitian Pendidikan. https://doi.org/10.25134/pedagogi.v7i1.2611

Sofyan, R. (2011). Bisnis Syariah Mengapa Tidak? (p. 208). Gramedia Pustaka Utama.

Subagiyo, R. (2019). Era Fintech: Peluang Dan Tantangan Bagi Ekonomi Syariah. El-Jizya: Jurnal Ekonomi Islam.

Subandi. (2011). Deskripsi Kualitatif Sebagai Satu Metode Qualitative Description as one Method in Performing Arts Study. Harmonia.

Sungkawaningrum, F. (2019). Eksplorasi peran perbankan syariah dalam memajukan industri halal di sektor makanan halal. Ekplorasi Peran Perbankan.... Wahana Islamika: Jurnal Studi Keislaman Vol. 5 No. 2 (2019) Pp. 32-17.

Swastiratu, C., Baga, L. M., \& Saptono, I. T. (2019). Banking And Financial Technology (Fintech) Islamic Integration With Collaborative Models. Russian Journal of Agricultural and Socio-Economic Sciences. https://doi.org/10.18551/rjoas.2019-07.11

Trimulato. (2020). Pengembangan UMKM Melalui Fintech Syariah di Tengah Wabah Covid-19. Jurnal Ekonomi Syariah Dan Hukum Ekonomi Syariah.

Utomo, S. B., Sekaryuni, R., Widarjono, A., Tohirin, A., \& Sudarsono, H. (2020). Promoting Islamic financial ecosystem to improve halal industry performance in Indonesia: a demand and supply analysis. Journal of Islamic Marketing. https://doi.org/10.1108/JIMA-12-2019-0259

Wahyuni, R. A. E. (2019). Perkembangan Ekonomi Islam Di Indonesia Melalui Penyelenggaraan Fintech Syariah. Mahkamah.

Winarto, W. (2020). Effect Of Sharia Financial Technology In Small And Medium Enterprises (SME). Annals of the University of Craiova for Journalism, Communication and Management.

Wiwin Yuliani. (2018). Metode Penelitian Deskriptif Kualitatif Dalam Perspektif Bimbingan dan Konseling. Quanta. 